\title{
AGE AND GROWTH RATE DYNAMICS OF AN OLD AFRICAN BAOBAB DETERMINED BY RADIOCARBON DATING
}

\author{
Adrian Patrut ${ }^{1,2} \cdot$ Diana H Mayne ${ }^{3} \cdot$ Karl F von Reden ${ }^{4,5} \cdot$ Daniel A Lowy ${ }^{6}$ Sarah Venter ${ }^{7} \bullet$ \\ Ann P McNichol ${ }^{2}$ Mark L Roberts ${ }^{2}$ Dragos Margineanu ${ }^{1}$
}

\begin{abstract}
In 2008, a large African baobab (Adansonia digitata L.) from Makulu Makete, South Africa, split vertically into 2 sections, revealing a large enclosed cavity. Several wood samples collected from the cavity were processed and radiocarbon dated by accelerator mass spectrometry (AMS) for determining the age and growth rate dynamics of the tree. The ${ }^{14} \mathrm{C}$ date of the oldest sample was found to be of $1016 \pm 22 \mathrm{BP}$, which corresponds to a calibrated age of $1000 \pm 15 \mathrm{yr}$. Thus, the Makulu Makete tree, which eventually collapsed to the ground and died, becomes the second oldest African baobab dated accurately to at least $1000 \mathrm{yr}$. The conventional growth rate of the trunk, estimated by the radial increase, declined gradually over its life cycle. However, the growth rate expressed more adequately by the cross-sectional area increase and by the volume increase accelerated up to the age of $650 \mathrm{yr}$ and remained almost constant over the past $450 \mathrm{yr}$.
\end{abstract}

\section{INTRODUCTION}

The African baobab (Adansonia digitata L.), a tropical angiosperm that belongs to the Malvaceae family, is found in the tropical arid savanna regions of central and southern Africa. The enormous girth reached by certain individuals, often out of proportion relative to their height, has generated much speculation about its age limit (Swart 1963; Guy 1970; Wickens 1983; von Breitenbach 1985; Wilson 1988; Esterhuyse et al. 2001; Pakenham 2004).

The faint growth rings produced by the African baobab, believed by many researchers to be annual rings (Wickens 1983, Esterhuyse et al. 2001; Robertson et al. 2006), cannot be used for dating fallen large and old trees. A hypothetically accurate ring count is not possible, as growth rings may no longer be observed in certain areas of the trunk of old baobabs and also because of the presence of large internal hollows. Hence, the only accurate method for aging baobabs is radiocarbon dating of wood samples collected from their trunk. There is a scarce number of disclosed studies on ${ }^{14} \mathrm{C}$ dating of African baobabs (Swart 1963; Robins and Swart 1964; Sheppard and Swart 1971; Robertson et al. 2006; Patrut et al. 2007, 2010). Up to the present, the oldest dated African baobab is Grootboom, a very large specimen that collapsed recently in Namibia and was investigated by accelerator mass spectrometry (AMS). According to the dating results, its calibrated age was at least $1275 \mathrm{yr}$ (Patrut et al. 2007).

In 2008, the large Makulu Makete tree collapsed partially and then totally to the ground, thus offering a good opportunity to investigate and date accurately a fallen old baobab. Here, we report the AMS ${ }^{14} \mathrm{C}$ dating results of samples collected from this baobab, in order to determine accurately its age and the growth rate dynamics during its life cycle.

\footnotetext{
${ }^{1}$ Department of Chemistry, Babes-Bolyai University, Arany Janos 11, 400028 Cluj-Napoca, Romania.

${ }^{2}$ Corresponding author. Email: apatrut@gmail.com.

${ }^{3}$ Baobab Trust, Box 1566, Parklands 2121, Johannesburg, South Africa.

${ }^{4}$ NOSAMS Facility, Department of Geology \& Geophysics, Woods Hole Oceanographic Institution, 360 Woods Hole Rd., Mailstop 8, Woods Hole, Massachusetts 02543, USA

${ }^{5}$ Corresponding author. Email: kvonreden@whoi.edu.

${ }^{6} \mathrm{FlexEl}$, LLC, College Park, Maryland 20742, USA.

${ }^{7}$ Restoration and Conservation Biology Research Group, School of Animal, Plant and Environmental Sciences, University of the Witwatersrand, PO WITS 2050, Johannesburg, Gauteng, South Africa.
}

C 2010 by the Arizona Board of Regents on behalf of the University of Arizona Proceedings of the 20th International Radiocarbon Conference, edited by A J T Jull RADIOCARBON, Vol 52, Nr 2-3, 2010, p 727-734 


\section{STUDY AREA AND METHODS}

\section{Makulu Makete Tree and Its Area}

The Makulu Makete Wildlife Reserve, located in the northwestern part of Limpopo Province, South Africa, lies adjacent to the border with Botswana., It is the home of several large baobabs. The Makulu Makete tree, called "big tree" or "big baobab" by the owners, was the largest tree in the reserve. It had a height of $24 \mathrm{~m}$, a circumference at breast height (cbh; $1.30 \mathrm{~m}$ above ground level) of $22.25 \mathrm{~m}$ and an estimated wood volume of $\sim 180 \mathrm{~m}^{3}$, see Figure 1. The GPS coordinates for the site are $22^{\circ} 34.584^{\prime} \mathrm{S}, 25^{\circ} 52.261^{\prime} \mathrm{E}$, with an altitude of $719 \mathrm{~m}$ and mean annual rainfall of $388 \mathrm{~mm}$.

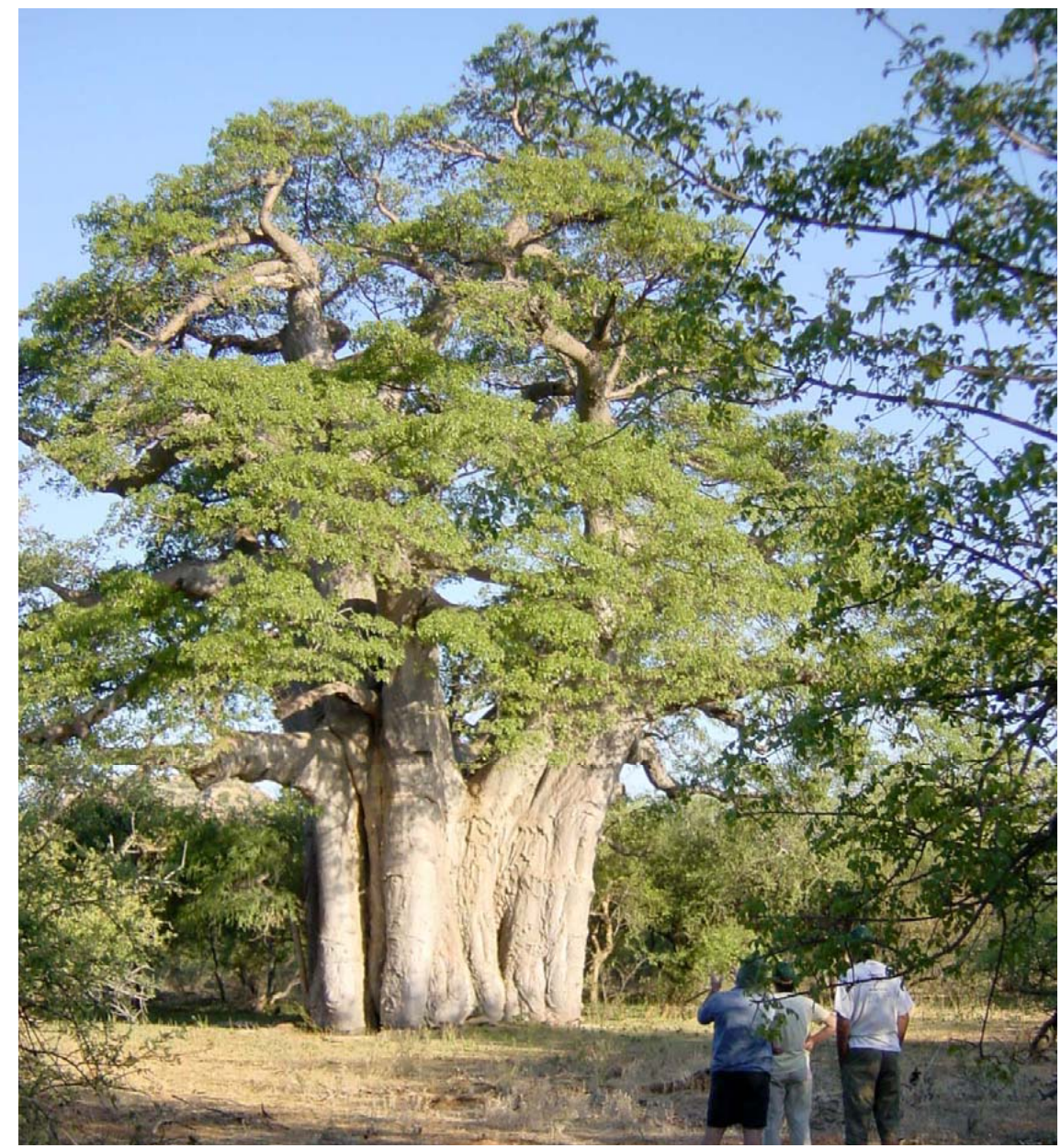

Figure 1 View from west of the Makulu Makete tree prior to its split

In June 2008, one half of the baobab was found lying on the ground. The tree had split vertically into 2 sections; the southern section had collapsed, while the northern one remained standing. As a result, a large quasi-central cavity was exposed in the northern section.

The cavity in the standing northern section, with a half-bell shape, had a length along the broken cross-section of $2.81 \mathrm{~m}$ at its base (which was at $2.10 \mathrm{~m}$ above ground level), a maximum width/ 
depth of $2.20 \mathrm{~m}$, and a maximum height of $2.70 \mathrm{~m}$ (see Figure 2). Investigation of the fallen southern section showed that approximately half of the cavity was located inside this part of the trunk. Eventually, the northern section also split into 2 parts and collapsed in November 2008. Today, the remains of the big baobab are lying on the ground in an advanced stage of decay.

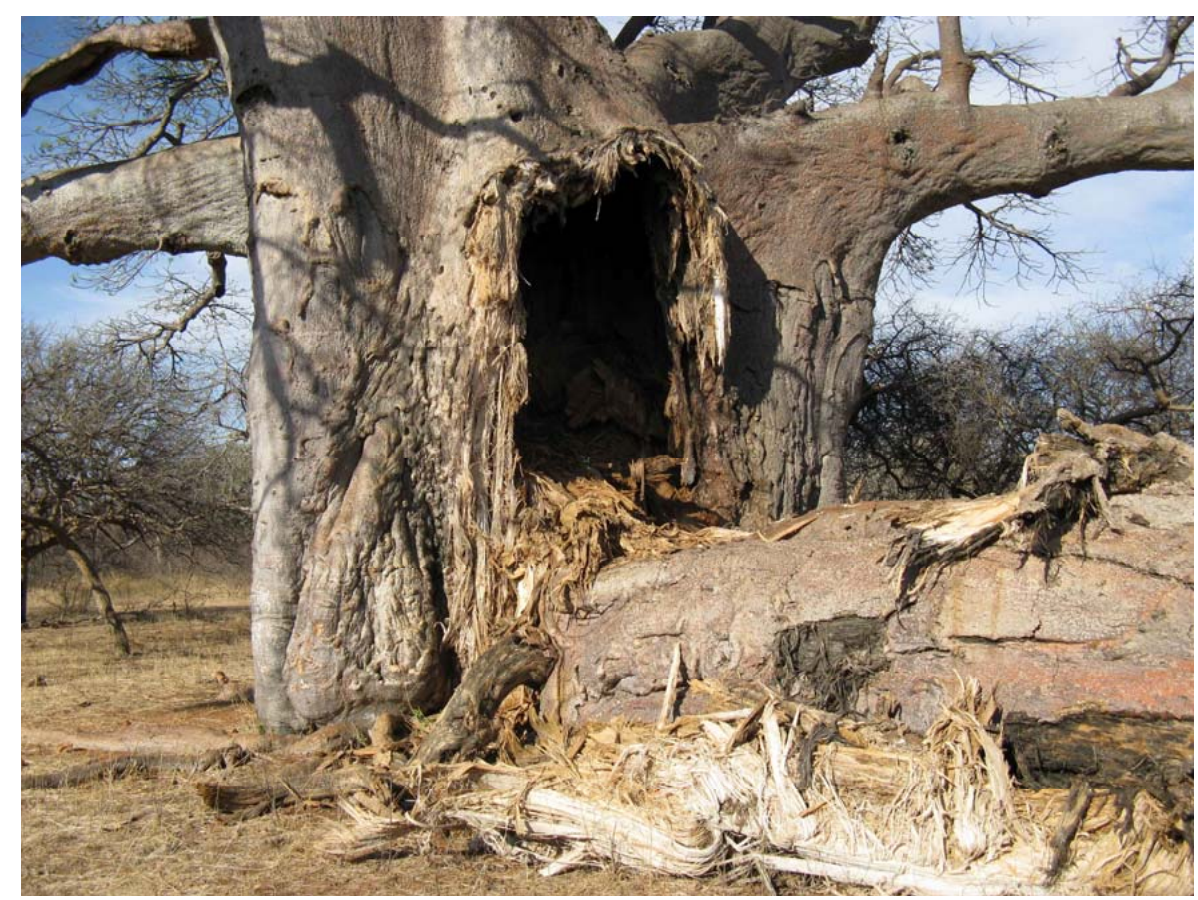

Figure 2 The northern section of the tree showing the cavity evinced after the southern section collapsed

Size measurements were performed by means of a tape. The height was calculated by considering the length of the collapsed southern section lying on the ground, which was taller than the northern section.

\section{Sample Collection}

Several wood samples were collected from the remaining cavity in the northern section (samples 15), when it was still standing, as well as from the fallen southern section (sample 6). The cross-sectional area at sampling height, i.e. $\sim 2.10 \mathrm{~m}$ above ground level, with the large cavity and sample positions are shown in Figure 3. An additional sample was extracted from a broken high branch of the southern section (sample 7). The samples were processed and investigated by AMS ${ }^{14} \mathrm{C}$ dating.

\section{Sample Preparation}

Baobab wood has a very low non-structural mobile carbon content. Statistical analysis indicated no significant differences between fraction modern $(\mathrm{Fm})$ values and ${ }^{14} \mathrm{C}$ dates for baobab wood samples investigated with pretreatment and without pretreatment (Patrut et al. 2010). Consequently, the wood samples collected from the Makulu Makete tree were analyzed without pretreatment, being combusted to $\mathrm{CO}_{2}$ by using the closed-tube combustion method (Sofer 1980). The resulting $\mathrm{CO}_{2}$ was reduced to graphite on iron catalyst, under hydrogen atmosphere (Vogel et al. 1984). Eventually, the graphite samples were analyzed by AMS. 


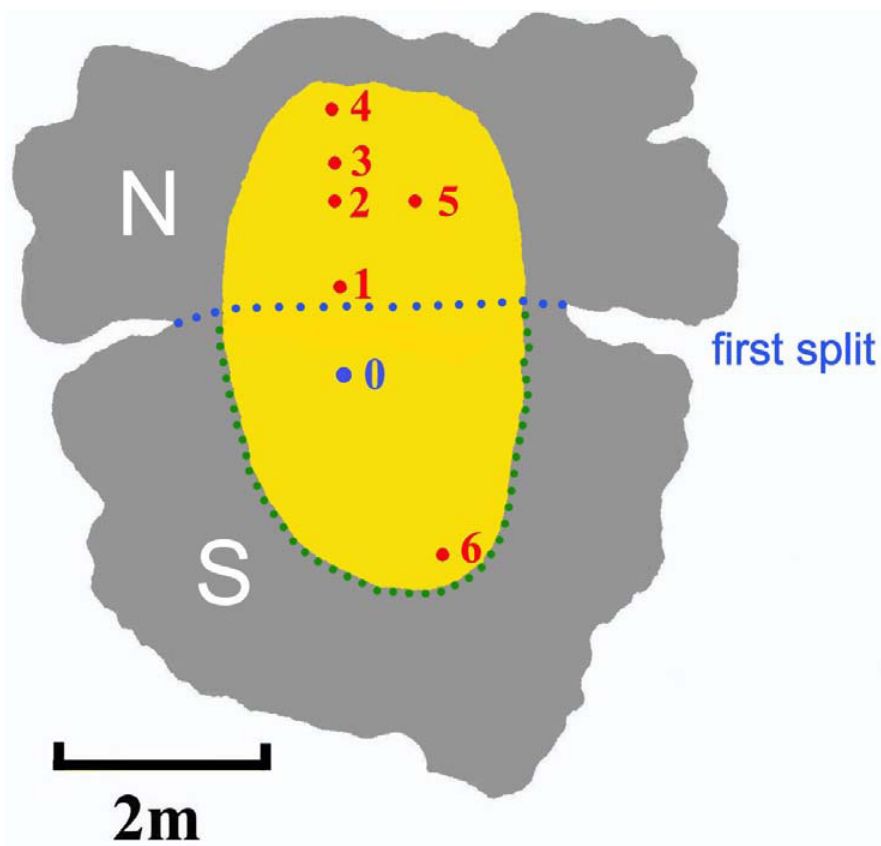

Figure 3 Cross-section of the trunk at a height of $2.10 \mathrm{~m}$ above ground level, showing the roughly oval-shaped internal cavity and sample positions inside the cavity.

\section{AMS Measurements}

${ }^{14} \mathrm{C}$ measurements were performed at the National Ocean Sciences AMS Facility of the Woods Hole Oceanographic Institution, by using the Pelletron tandem 500kV AMS system (Roberts et al. 2010). The surface of the graphite samples was sputtered with cesium ions and the secondary negative ions were extracted and accelerated in the AMS system. ${ }^{12} \mathrm{C}$ and ${ }^{13} \mathrm{C}$ ions were measured in Faraday cups, where a ratio of their currents was recorded. Simultaneously, ${ }^{14} \mathrm{C}$ ions were recorded in a solid state detector, so that instantaneous ratios of ${ }^{14} \mathrm{C}$ to ${ }^{12} \mathrm{C}$ were also recorded. These raw signals were compared to ratios obtained with a known standard material (oxalic acid I, NIST-SRM-4990) and converted to a $\mathrm{Fm}$ value, which was corrected for isotopic fractionation with the normalized $\delta^{13} \mathrm{C}$ value of $-25 \%$. Fm values were ultimately converted to ${ }^{14} \mathrm{C}$ dates.

\section{Calibration}

Fm values were calibrated and converted into calendar ages with OxCal v 4.1 for Windows (Bronk Ramsey 1995, 2001), by using the IntCal04 atmospheric data set (Reimer et al. 2004).

\section{RESULTS AND DISCUSSION}

\section{AMS Results and Calibrated Ages}

Fm values and ${ }^{14} \mathrm{C}$ dates of samples are listed in Table $1 .{ }^{14} \mathrm{C}$ dates and errors were rounded to the nearest year. Calibrated (cal) ages are also displayed in Table 1 . The 1- $\sigma$ probability distribution was chosen to calculate calibrated age ranges. For 3 samples $(1,2,6)$, the $1-\sigma$ distribution corresponds only to 1 range. In the case of 4 samples $(3,4,5,7)$, the $1-\sigma$ distribution corresponds to 2 ranges of calendar years. For these 4 samples, the confidence interval of 1 range (marked in bold) is much 
greater than of the other, and it was selected as the most probable cal AD range for the purpose of this discussion.

Table 1 AMS dating results and calibrated calendar ages.

\begin{tabular}{|c|c|c|c|c|c|c|}
\hline $\begin{array}{l}\text { Sample } \\
\text { code }\end{array}$ & $\begin{array}{l}\text { NOSAMS } \\
\text { accession } \\
\mathrm{nr}\end{array}$ & $\begin{array}{l}\text { Radius }^{\mathrm{a}} / \\
\text { Height }^{\mathrm{b}} \\
(\mathrm{m})\end{array}$ & $\begin{array}{l}\text { Fraction } \\
\text { modern } \\
\text { [error] }\end{array}$ & $\begin{array}{l}{ }^{14} \mathrm{C} \text { date } \\
\text { [error] } \\
\left({ }^{14} \mathrm{C} \text { yr BP }\right) \\
\end{array}$ & $\begin{array}{l}\text { Cal AD range(s) } \\
1-\sigma \\
\text { [confidence interval] }\end{array}$ & $\begin{array}{l}\text { Sample age } \\
\text { [error] } \\
\text { (cal yr) }\end{array}$ \\
\hline 1 & OS-69057 & $0.90 / 2.10$ & $\begin{array}{l}0.8812 \\
{[ \pm 0.0027]}\end{array}$ & $1016[ \pm 22]$ & 994-1025 [68.2\%] & $1000[ \pm 15]$ \\
\hline 2 & OS-71903 & $1.80 / 2.10$ & $\begin{array}{l}0.9081 \\
{[ \pm 0.0029]}\end{array}$ & $774[ \pm 23]$ & $1225-1272[68.2 \%]$ & $760[ \pm 25]$ \\
\hline 3 & OS-71909 & $2.10 / 2.10$ & $\begin{array}{l}0.9287 \\
{[ \pm 0.0032]}\end{array}$ & $594[ \pm 26]$ & $\begin{array}{l}\mathbf{1 3 1 2}-\mathbf{1 3 5 9}[\mathbf{5 3 . 8 \%}] \\
1388-1401[14.4 \%]\end{array}$ & $675[ \pm 25]$ \\
\hline 4 & OS-71902 & $2.70 / 2.10$ & $\begin{array}{l}0.9618 \\
{[ \pm 0.0034]}\end{array}$ & $313[ \pm 27]$ & $\begin{array}{l}\mathbf{1 5 2 1}-\mathbf{1 5 9 1}[\mathbf{5 2 . 3 \%} \\
1620-1642[15.9 \%]\end{array}$ & $450[ \pm 35]$ \\
\hline 5 & OS-71906 & $1.95 / 2.10$ & $\begin{array}{l}0.9168 \\
{[ \pm 0.0035]}\end{array}$ & $698[ \pm 28]$ & $\begin{array}{l}\mathbf{1 2 7 1}-\mathbf{1 2 9 9}[\mathbf{5 7 . 9 \%}] \\
1370-1380[10.3 \%]\end{array}$ & $730[ \pm 10]$ \\
\hline 6 & OS-72139 & $2.00 / 2.10$ & $\begin{array}{l}0.9082 \\
{[ \pm 0.0037]}\end{array}$ & $773[ \pm 30]$ & $1225-1273[68.2 \%]$ & $760[ \pm 25]$ \\
\hline 7 & OS-73252 & $-/ 15.00$ & $\begin{array}{l}0.9296 \\
{[ \pm 0.0033]}\end{array}$ & $588[ \pm 27]$ & $\begin{array}{l}\mathbf{1 3 1 5}-\mathbf{1 3 5 6}[\mathbf{4 9 . 5 \%} \\
1309-1385[14.7 \%]\end{array}$ & $675[ \pm 20]$ \\
\hline $0^{\mathrm{d}}$ & - & $0 / 2.10$ & - & - & 一 & $1100[ \pm 50]^{\mathrm{e}}$ \\
\hline
\end{tabular}

${ }^{a}$ Distance from hypothetical center of the trunk at sampling height, i.e. $2.10 \mathrm{~m}$.

${ }^{\mathrm{b}}$ Height above ground level.

cIn 2008.

${ }^{\mathrm{d}}$ Theoretical center of the trunk at sampling height

eEstimated value.

In order to obtain single calendar age values of samples, needed especially for calculating growth rates, we derived a mean calendar age of each sample from the 1- $\sigma$ range with the highest probability. Calendar ages of samples represent the difference between AD 2008 (when the tree died) and the mean value of the selected $1-\sigma$ range, with the corresponding error. Calendar ages of samples and errors were rounded to the nearest $5 \mathrm{yr}$.

Calendar ages of samples are presented by analogy with ${ }^{14} \mathrm{C}$ dates, i.e. by a mean value and the error that cover the respective 1- $\sigma$ range. It is obvious that the probability curve and the relative area of a certain $1-\sigma$ range is usually not perfectly symmetrical around the mean value, the latter being calculated as the arithmetic mean of the upper and lower limits of the range. However, as the 1- $\sigma$ ranges of the 7 samples span only over a few decades of cal years and because the obtained mean calendar ages and corresponding errors are rounded to the nearest $5 \mathrm{yr}$, our attempt to derive mean calendar ages can be considered mathematically acceptable.

The ${ }^{14} \mathrm{C}$ date of sample 1 , which is the oldest, was found to be $1016 \pm 22 \mathrm{BP}$ ( $\mathrm{Fm}=0.8812 \pm 0.0027$ ), which corresponds to a calibrated calendar age of $1000 \pm 15 \mathrm{yr}$. The age of sample 7, which originates from a collapsed and broken high branch of the southern section, indicates that the respective branch belonged to the original crown structure of the tree and not to a possible later crown reconstruction.

For calibration, we used the general IntCal04 data set (Reimer et al. 2004) and not the SHCal04 data set for the Southern Hemisphere (McCormac et al. 2004), as the latter does not yet contain information for lower southern latitudes and does not include results from Africa for the time period corre- 
sponding to sample ages. The offset between calibrated ages obtained when using the 2 calibration curves is of several decades (McCormac et al. 2002, 2004).

\section{Age of the Tree}

The northern section was shorter and, due to several large branches, more massive than the southern section, which was taller and slimmer. In addition, prior to the first split, the 2 sections were partially delimited by deep incisions in the trunk. These details, combined with the big dimensions and the first split of the trunk along the deep incisions line, suggested that the investigated baobab could have been a double-stemmed tree. However, dating results and the sequence of sample ages demonstrate convincingly that it was a single-stemmed tree (with a single pith/center at a given height of the trunk).

In order to determine the age of the tree, it was necessary to identify the position of the pith/center of the trunk at sampling height, i.e. $2.10 \mathrm{~m}$ above ground level, which was called the hypothetical or theoretical sample 0 . Based on the position of sample 1, the sequence of sample ages, and the corresponding cross-section, we estimated the position of the pith/center at sampling height with an error of $\pm 0.30 \mathrm{~m}$ in all directions. We consider that the pith/center (sample 0 ) was located inside the cavity, in the southern section of the trunk, close to the line of the first split and somewhat shifted laterally toward the most northern and western points of the trunk, as shown in Figure 3. According to its position and to literature data on growth rates of baobabs (von Breitenbach 1985; Wickens and Lowe 2008), the age of the Makulu Makete tree can be estimated to $1100 \pm 50 \mathrm{yr}$ at the time it died.

\section{Growth Rate Dynamics}

For determining the growth rate dynamics of the trunk, we used ages of 3 samples $(1,2$, and 4$)$ and the estimated age in the pith/center (sample 0 ). The 4 samples were collected from sites located at equal distances $(0.90 \mathrm{~m})$ along the same radius, which was of $3.60 \mathrm{~m}$.

The growth rate dynamics are estimated conventionally by the mean radial increase over different time periods, as shown in Table 2. As expected, the increase in radius declined gradually over the 4 investigated timeframes. According to the dating results, the trunk of the Makulu Makete tree took $100 \mathrm{yr}$ (estimated value), $240 \mathrm{yr}, 310 \mathrm{yr}$, and $450 \mathrm{yr}$ for the 4 successive radial increases of $0.90 \mathrm{~m}$ each. One can conclude that the trunk reached a length of $1.80 \mathrm{~m}$ after $100 \mathrm{yr}$ (estimated value), $3.60 \mathrm{~m}$ after $340 \mathrm{yr}, 5.40 \mathrm{~m}$ after $650 \mathrm{yr}$, and $7.20 \mathrm{~m}$ after $1100 \mathrm{yr}$, along the north-south chord (quasi-diameter) on which the 4 samples were positioned. As the trunk had practically no notable taper up to the forking area, these figures can be considered quasi-identical from ground level up to a height of $\sim 4.80 \mathrm{~m}$. The maximum length values of the trunk, prior to collapse, were of $7.44 \mathrm{~m}$ (east to west) and $\sim 8.00 \mathrm{~m}$ (north to south).

Table 2 Growth rate dynamics expressed by the mean radial increase

\begin{tabular}{|c|c|c|c|c|c|c|c|c|}
\hline \multicolumn{2}{|c|}{ Sample code } & \multicolumn{2}{|c|}{$\begin{array}{c}\text { Radius }^{\mathrm{a}} \\
r \\
(\mathrm{~m}) \\
\end{array}$} & \multirow{2}{*}{$\begin{array}{l}\text { Radius } \\
\text { difference } \\
\Delta r=r_{B}-r_{A} \\
\text { (m) }\end{array}$} & \multicolumn{2}{|c|}{$\begin{array}{c}\text { Sample age } \\
t \\
(\mathrm{yr}) \\
\end{array}$} & \multirow{2}{*}{$\begin{array}{l}\text { Age } \\
\text { difference } \\
\Delta t=t_{A}-t_{B} \\
(\mathrm{yr})\end{array}$} & \multirow{2}{*}{$\begin{array}{l}\text { Mean radial } \\
\text { increase } \\
\Delta r / \Delta t \\
\left(10^{-3} \mathrm{~m} \mathrm{yr}^{-1}\right)\end{array}$} \\
\hline A & $\mathrm{B}$ & $\mathrm{A}$ & $\mathrm{B}$ & & $\mathrm{A}$ & $\mathrm{B}$ & & \\
\hline 0 & 1 & 0 & 0.9 & 0.90 & $1100^{\mathrm{b}}$ & 100 & $100^{\mathrm{b}}$ & $9.00^{\mathrm{b}}$ \\
\hline 1 & 2 & 0.9 & 1.8 & 0.9 & 1000 & 7 & 240 & 3.75 \\
\hline 2 & 4 & & 2. & 0.9 & 76 & 450 & 31 & 2.90 \\
\hline 4 & adjacent to bark & 2.70 & 3.60 & 0.90 & 450 & 0 & 450 & 2.00 \\
\hline
\end{tabular}

${ }^{a}$ Distance from hypothetical center of the trunk at sampling height, i.e. $2.10 \mathrm{~m}$ (sample 0 ).

${ }^{\mathrm{b}}$ Estimated values. 
However, the mean radial increase expresses only an apparent growth rate of the trunk. Given that trees grow in 3 dimensions, their size is much more accurately expressed by the wood volume of the trunk, which is in proportion with the cross-sectional areas at different heights. Therefore, the area increase and volume increase are much more precise estimates of the growth rate as compared to the radial increase. This is why we also calculated the mean area increase, in circular approximation, and the mean volume increase up to sampling height, in cylindrical approximation (see Table 3). Because the trunk of baobabs deviates more or less from cylindrical symmetry (in vertical section) and especially from circular symmetry (in horizontal sections), the displayed figures are overestimated. Nevertheless, the respective values demonstrate that the "true" growth rate of the trunk accelerated considerably up to the age of $650 \mathrm{yr}$ and remained almost constant thereafter, i.e. over the past $450 \mathrm{yr}$.

Table 3 Growth rate dynamics expressed by the mean cross-sectional area increase and mean volume increase.

\begin{tabular}{|c|c|c|c|c|c|c|c|c|c|c|c|c|}
\hline \multicolumn{2}{|c|}{$\begin{array}{c}\text { Sample } \\
\text { code }\end{array}$} & \multicolumn{2}{|c|}{$\begin{array}{c}\text { Cross-sec- } \\
\text { tional area } \\
S \\
\left(\mathrm{~m}^{2}\right)\end{array}$} & \multicolumn{2}{|c|}{$\begin{array}{c}\text { Volume } \\
\qquad \\
\left(\mathrm{m}^{3}\right)\end{array}$} & \multirow{2}{*}{$\begin{array}{l}\text { Area } \\
\text { diff. } \\
\Delta S= \\
S_{B}-S_{A} \\
\left(\mathrm{~m}^{2}\right)\end{array}$} & \multirow{2}{*}{$\begin{array}{l}\text { Volume } \\
\text { diff. } \\
\Delta V= \\
V_{B}-V_{A} \\
\left(\mathrm{~m}^{3}\right)\end{array}$} & \multicolumn{2}{|c|}{$\begin{array}{c}\text { Sample age } \\
t \\
(\mathrm{yr})\end{array}$} & \multirow{2}{*}{$\begin{array}{l}\text { Age } \\
\text { diff. } \\
\Delta t= \\
t_{A}-t_{B} \\
\text { (yr) }\end{array}$} & \multirow{2}{*}{$\begin{array}{l}\text { Mean cross- } \\
\text { sectional } \\
\text { area increase } \\
\Delta S / \Delta t \\
\left(10^{-3} \mathrm{~m}^{2} \mathrm{yr}^{-1}\right)\end{array}$} & \multirow{2}{*}{$\begin{array}{l}\text { Mean } \\
\text { volume } \\
\text { increase } \\
\Delta V / \Delta t \\
\left(10^{-3} \mathrm{~m}^{3} \mathrm{yr}^{-1}\right)\end{array}$} \\
\hline A & B & A & B & A & B & & & $\mathrm{A}$ & B & & & \\
\hline 0 & 1 & 0 & 2.54 & 0 & 5.34 & 2.54 & 5.34 & $1100^{\mathrm{c}}$ & 1000 & $100^{\mathrm{c}}$ & $25.40^{\mathrm{c}}$ & $53.40^{\mathrm{c}}$ \\
\hline 1 & 2 & 2.54 & 10.18 & 5.34 & 21.38 & 7.64 & 16.04 & 1000 & 760 & 240 & 31.83 & 66.83 \\
\hline 2 & 4 & 10.18 & 22.90 & 21.38 & 48.09 & 12.72 & 26.71 & 760 & 450 & 310 & 41.03 & 86.16 \\
\hline 4 & $\begin{array}{l}\text { adja- } \\
\text { cent } \\
\text { to bark }\end{array}$ & 22.90 & 40.72 & 48.09 & 85.50 & 17.82 & 37.41 & 450 & 0 & 450 & 39.60 & 83.13 \\
\hline
\end{tabular}

a Trunk area at sampling height, i.e. $2.10 \mathrm{~m}$ (in circular approximation).

${ }^{\mathrm{b}}$ Trunk volume from ground level up to sampling height (in cylindrical approximation).

${ }^{\mathrm{c} E s t i m a t e d ~ v a l u e s . ~}$

According to a limited amount of research, the growth rate of the African baobab declines dramatically in the final stage of its life cycle, which can span over several centuries (Guy 1970; von Breitenbach 1985). This significant slowing down of growth was also observed in the case of Dorslandboom and Grootboom, the iconic baobabs from Namibia, which had very low growth rates over the last centuries of their life (Patrut et al. 2007, 2010). Dating results and calculated growth rate values demonstrate, however, that the Makulu Makete tree did not reach the ultimate stage of the African baobab's life cycle, when baobabs almost stop growing, and suggest that it did not die of old age. Its death was possibly due to the progress of the cavitation process, which almost cut the trunk along a deep incisions line, making the tree mechanically unstable. Eventually, the unstable trunk split in 2 stages into 3 vertical sections, which collapsed to the ground.

\section{CONCLUSIONS}

According to AMS ${ }^{14} \mathrm{C}$ analysis, the Makulu Makete tree becomes the second oldest African baobab that was accurately dated to at least $1000 \mathrm{yr}$. The reported dating results provide additional evidence for the long-lived baobab hypothesis, according to which certain individuals of this species are millenarian trees.

Sample ages combined with sample positions suggest that the common statement according to which the growth rate of baobabs declines gradually over their life is not true, being a consequence of the conventional evaluations, based exclusively on the radial increase of the trunk. In the case of 
the Makulu Makete tree, the growth rate of the trunk measured by the cross-sectional area increase and/or by the volume increase accelerated up to the age of $650 \mathrm{yr}$ and remained almost constant over the next $450 \mathrm{yr}$ of its life.

Dating results and particularly the calculated growth rate dynamics of the Makulu Makete tree can be regarded as a benchmark for future age determination of other large African baobabs.

\section{ACKNOWLEDGMENTS}

Authors would like to thank the generous help provided by Peter Philip and Jane Chidgey of Makulu Makete Wildlife Reserve. This material is based on work supported by a grant from the Romanian National University Research Council (PN II - IDEI 2354 Nr. 1092) and by US National Science Foundation under Cooperative Agreement OCE-022828996.

\section{REFERENCES}

Bronk Ramsey C. 1995. Radiocarbon calibration and analysis of stratigraphy: the OxCal program. Radiocarbon 37(2):425-30.

Bronk Ramsey C. 2001. Development of the radiocarbon calibration program. Radiocarbon 43(2A):355-63.

Esterhuyse N, von Breitenbach J, Söhnge H. 2001. Remarkable Trees of South Africa. Pretoria: Briza. p 157-8.

Guy GL. 1970. Adansonia digitata and its rate of growth in relation to rainfall in South Central Africa. Proceedings and Transactions of the Rhodesia Scientific Association 54(2):68-84.

McCormac FG, Reimer PJ, Hogg AG, Higham TFG, Baillie MGL, Palmer J, Stuiver M. 2002. Calibration of the radiocarbon time scale for the Southern Hemisphere: AD 1850-950. Radiocarbon 44(3):641-51.

McCormac FG, Hogg AG, Blackwell PG, Buck CE, Higham TFG, Reimer PJ. 2004. SHCal04 Southern Hemisphere calibration, 0-11.0 cal kyr BP. Radiocarbon 46(3): 1087-92.

Pakenham T. 2004. The Remarkable Baobab. New York: Norton. p 13-4.

Patrut A, von Reden K, Lowy DA, Alberts AH, Pohlman JW, Wittmann R, Gerlach D, Xu L, Mitchell CS. 2007. Radiocarbon dating of a very large African baobab. Tree Physiology 27(11):1569-74.

Patrut A, von Reden K, Lowy DA, Mayne DH, Elder KE, Roberts ML, McNichol AP. 2010. Comparative AMS radiocarbon dating of pretreated versus non-pretreated tropical wood samples. Nuclear Instruments and Methods in Physics Research B 268(7-8):910-3.

Reimer PJ, Baillie MGL, Bard E, Bayliss A, Beck JW, Bertrand CJH, Blackwell PG, Buck CE, Burr GS, Cutler KB, Damon PE, Edwards RL, Fairbanks RG, Friedrich M, Guilderson TP, Hogg AG, Hughen KA, Kromer B, McCormac G, Manning S, Bronk Ramsey C, Reimer RW, Remmele S, Southon JR, Stuiver M, Talamo S, Taylor FW, van der Plicht J, Weyhenmeyer
CE. 2004. IntCal04 terrestrial radiocarbon age calibration, 0-26 cal kyr BP. Radiocarbon 46(3):1029-58.

Roberts ML, Burton JR, Elder KL, Longworth BE, McIntyre CP, von Reden KF, Han BX, Rosenheim BE, Jenkins WJ, Galutschek E, McNichol AP. 2010. A high-performance ${ }^{14} \mathrm{C}$ accelerator mass spectrometry system. Radiocarbon 52(2-3):228-35.

Robertson J, Loader NJ, Froyd CA, Zambatis N, Whyte I, Woodborne S. 2006. The potential of the baobab (Adansonia digitata $\mathrm{L}$.) as a proxy climate archive. Applied Geochemistry 21(10):1674-80.

Robins PA, Swart ER. 1964. Southern Rhodesian radiocarbon measurements I. Radiocarbon 6(1):31-6.

Sheppard JG, Swart ER. 1971. Rhodesian radiocarbon measurements IV. Radiocarbon 13(2):420-31.

Sofer Z. 1980. Preparation of carbon dioxide for stable carbon isotope analysis of petroleum fractions. Analytical Chemistry 52(8):1389-91.

Swart ER. 1963. Age of the baobab tree. Nature 198(4881):708-9.

Vogel JS, Southon JR, Nelson DE, Brown TA. 1984. Performance of catalytically condensed carbon for use in accelerator mass spectrometry. Nuclear Instruments and Methods in Physics Research B 5(2):289-93.

von Breitenbach F. 1985. Aantekeninge oor die groeitempo van aangeplante kremeteartbome (Adansonia digitata) en opmerkinge ten opsigte van lewenstyd, groeifases en genetiese variasie van die spesie. Journal of Dendrology 5(1-2):1-21.

Wickens GE. 1983. The baobab: Africa's upside-down tree. Kew Bulletin 37(2):173-209.

Wickens GE, Lowe P. 2008. The Baobabs: Pachycauls of Africa, Madagascar and Australia. Dordrecht: Springer. $498 \mathrm{p}$.

Wilson RT. 1988. Vital statistics of the baobab (Adansonia digitata). African Journal of Ecology 26(3):197206. 